\title{
Viability and Length of Above-Ground Part of White Clover in Polluted Soil
}

\author{
Asta Strèlkutè, Jolita Bradulienè \\ Vilnius Gediminas technical university, Environmental protection department, \\ Sauletekio ave. 11, LT-10223 Vilnius, Lithuania
}

\begin{abstract}
Dustiness on gravel roads and slippery in winter is reduced through the application of various dustiness and slippery minimization materials, most frequently - calcium chloride. However, global efforts have been intensified to find new effective materials making the least possible damage to the environmental components. Some of them is molasses based material and bishophit (technical magnesium chloride with additives). The investigations described in this paper were carried out by means of the method on the growth of grass vegetation in the contaminated soil. The aim of these investigations is to determine the impact of material for the road maintenance on the viability of herbaceous vegetation and the length of above-ground part. One herbaceous plant species have been selected for the investigations: white clover (L. Trifolium trepens). This species often grow on the roadsides of roads and are used for the recultivation of nearby pastures. Investigations shows that after 4 weeks growing, white clover germinated in polluted soil: with molasses based material $(10 \%, 20 \%, 30 \%)$ viability was $76-87 \%$, with mixture of molasses based material $(10 \%, 20 \%, 30 \%)$ and calcium chloride $(36.5 \%)$ was $0 \%$, with bishophit $(9,12,46 \mathrm{ml})$ was $1 \%$. Greatest length of above-ground part was determined in soil polluted with $10 \%$ molasses based material. Length was $4.10 \mathrm{~cm}$.
\end{abstract}

Keywords: white clover, molasses based material, calcium chloride, bishophit, polluted soil.

\begin{tabular}{|l|}
\hline Nomenclature \\
$\mathrm{MBM} \quad$ molasses based material \\
$\mathrm{CaCl}_{2} \quad$ calcium chloride \\
\hline
\end{tabular}

\section{Introduction}

Road maintenance is an important aspect in order to ensure safe migration of people. Non-slip, practicables tracks and rouds are safer to allow people to walk and ride. The biggest danger on the road staying during the winter time. Dropping the first snow starts and road maintenance companies working season.

For road maintenance use chemical reagents selected on the basis of the economic indicators are important to their physical and chemical properties.

Attention is drawn to the technical and sanitary characteristics of transporting and storage. The final choice of the reagent must be taken into account, as they affect vehicles, road surface and vegetation [1].

In practice it is known by various reagents designed to ensure traffic safety. Each country uses the optimal reagents by their financial capacities and material efficiency. One of the most important aspects when choosing a type of salt is its reliability effectively dissolves the snow and reduces slipperiness. Becoming more stringent environmental requirements has increasingly focused on the environmental impact of salt.

Vegetation can be affected by the salt in two ways: directly (while applying the leaf) and indirectly (through the soil and ground water). In one way or another, if introduced salt into the plants slow down their growth, disrupts other physiological characteristics. Salt affect areas therefore slows photosynthesis and slows water evaporation [2]. 
Different plant species can only raise a certain amount of salt. Chloride effects on vegetation caused the temperature conditions of the vegetation period, soil nature, scattered amount of salt, the duration of exposure. Roads, which used less salt, have a lower effect on plants [3-4].

Roadside vegetation plays an important role in the road environment. Vegetation cover allows restoring the balance of the natural environment, which disrupts the development of road infrastructure. In addition, the proper selection of plant species effectively protects the road surface slopes from erosion and reduces the likelihood of landslides [5].

White clover (Trifolium repens L.) - Lithuania growing perennial plant. They are low demanding on the soil. Most like to grow in humus soils, but detected and limed loams. Good soil conditions to survive for 8-10 years [6].

White clover - one of the most valuable fodder plants to the nutritional content. Lithuania used as feed for livestock. When sown with grasses, food is high in protein. In addition, white clover legume bacteria accumulate atmospheric nitrogen, enriching the soil with nitrogen materials. White clover varieties must not only bring a rich yield of herbs, but it has to be stable from year to year, regardless of what kind of weather conditions. Plant breeding is very important genotypeenvironment interaction [7].

White clover seldom roots deeper than $0.9 \mathrm{~m}$, which makes it adapted to shallow soils when adequate moisture is available.

Secondary roots developing from the stolon are mainly shallow $(0.2 \mathrm{~m})$ but can extend to $0.75-1.5 \mathrm{~m}$ in deep, friable soils.

Stands regenerate themselves both by reseeding and by vegetative growth.

The plants can reach a height of $20-30 \mathrm{~cm}$, but are normally $10-15 \mathrm{~cm}$ tall.

White clover can be relied upon as a soil conservation tool to preserve valuable topsoil on sloping fields or other erosionprone areas [8].

The investigation used polluted soil: with molasses based material, molasses based material and calcium chloride, with bishophit.

Magnesium chloride is a chemical compound whose name given by the formula. These salts are typical ionic halides are very soluble in water. Hydrated magnesium chloride can be extracted from sea water [9]. Salinity ranges up to 35\% [10]. Anhydrous magnesium chloride is the principal precursor to magnesium. Magnesium chloride under various conditions can be different shapes.

Magnesium chloride is formed naturally as a mineral bishophit $\left(\mathrm{MgCl}_{2} \cdot 6 \mathrm{H}_{2} \mathrm{O}\right)$, which is obtained from bulk evaporation of seawater. German scientist Gustav Bischoff was the first one who discovered there formed salts [9].

Pure bishophit crystals are transparent in color, but depending on the impurities consisting can be white or pink. It is a bitter-salty, spicy and has a burning taste, its hardness is 1.5 , electrically conductive, the specific weight -1.59 to 1.6 . Bishophit is very hygroscopic, melts under the open sky.

Bishophit is a stable product that does not convert into the environment. High concentrations in the environment causes danger to aquatic organisms, especially fish, daphnia and smaller aquatic organisms.

Bishophit can stimulate to salinity of the soil, which can lead to worse vegetation development. It also degrades water organoleptic and physico-chemical properties of the water gives the bitter taste, increases the hardness of the water.

Molasses is a secondary agricultural product derived from sugar production waste. Molasses-based material containing minerals: calcium, phosphorus, sulfur, chloride, sulfate. Molasses is composed of approximately $20 \%$ of sucrose, $20 \%$ of the sugar, $10 \%$ of ash $20 \%$ organic sugar-free product and $20 \%$ of water.

The material is a dark brown liquid, can be mixed with all the technical maintenance of road salts [11].

Molasses based material can be used for road maintenance both in the summer season (the gravel road dust reduction) and in the winter season (the road slippery minimization). Molasses based material has a dual effect on the ice - it dissolves and helps bounce off the road surface and prevents the formation of new. In addition, this material is biologically decomposes. The most popular use of this material is injection into the sodium chloride solution. The solution is prepared in a ratio of $90 \%$ sodium chloride and $10 \%$ molasses based materials [12].

This material can be used during the summer season dust reduction in urban areas, by inserting into the water for watering streets.

The aim of the investigation is to determine the impact of road maintenance liquid materials on the viability and length of the above-ground part of grass vegetation.

\section{Object and methodology}

\subsection{Determination of the seed viability of grass vegetation}

The investigation covered 100 units of the selected species of grass vegetation.

Continuous humidity was maintained throughout the investigation as water is the factor which regulates the viability of seeds [13]. Natural lighting was maintained which changed depending on the time of the day. The average prevailing temperature was $22{ }^{\circ} \mathrm{C}$. A bowl was lined with filter paper which was constantly humidified. Seeds were spread on the paper.

Seed viability (\%) was determined after 7 days. 


\subsection{Investigation of the growth of grass vegetation in soil contaminated with road maintenance solutions}

The investigation employed black peat, a mixture of organic fertiliser and humus with the following parameters of quality: humidity up to $60 \%$, acidity -7.2 , mineral nitrogen amount $156 \mathrm{mg} / \mathrm{kg}$, phosphorus $-105 \mathrm{mg} / \mathrm{kg}, \mathrm{potassium}-847 \mathrm{mg} / \mathrm{kg}$, calcium - $288 \mathrm{mg} / \mathrm{kg}$, magnesium - $57 \mathrm{mg} / \mathrm{kg}$, organic matter content - 92-96\%, acidity $\mathrm{pH}-5.5-6.5$, electrical conductivity $-1.0-1.5 \mathrm{mS} / \mathrm{m}$.

Temperature, air humidity and pressure were measured with a microclimate parameter meter with the measurement limits $(0 \ldots+40){ }^{\circ} \mathrm{C},(0 \ldots 100) \%,(700 \ldots 800) \mathrm{mm}$ of $\mathrm{Hg}$ column, and measurement errors $\pm 1,0{ }^{\circ} \mathrm{C}, \pm 5 \%, \pm 5 \mathrm{~mm}$ of $\mathrm{Hg}$ column.

The length of above-ground parts of the plants was measured with callipers with measurement limits ranging from $0 \mathrm{~mm}$ to 155 and measurement error was $0.1 \mathrm{~mm}$.

Seed viability was calculated as follows: one germinated plant was equated to $1 \%$ (100 seeds were seeded which accounts for $100 \%)$.

100 seeds of selected species of grass vegetation were sown in plastic pots with a soil content of $1 \mathrm{~kg}$ in each. Three aqueneous molasses based material (MBM) concentrations $(10 \%, 20 \%, 30 \%)$, three mixtures with $36.5 \%$ of $\mathrm{CaCl}_{2}$ and three bishophit $(9 \mathrm{ml}, 12 \mathrm{ml}, 46 \mathrm{ml})$ concentration were used during the investigation. Also, control plants were sown in soil untreated with solutions.

The total volume of each solution was $100 \mathrm{ml}$. The composition was as follows:

$-10 \mathrm{ml}$ of MBM solution and $90 \mathrm{ml}$ of water;

$-20 \mathrm{ml}$ of MBM solution and $80 \mathrm{ml}$ of water;

$-30 \mathrm{ml}$ of MBM solution and $70 \mathrm{ml}$ of water;

$-5 \mathrm{ml}$ of MBM solution, $45 \mathrm{ml}$ of water, $24.8 \mathrm{~g}$ of $\mathrm{CaCl}_{2}$ dissolved in $50 \mathrm{ml}$ of water;

$-10 \mathrm{ml}$ of MBM solution, $40 \mathrm{ml}$ of water, $24.8 \mathrm{~g}$ of $\mathrm{CaCl}_{2}$ dissolved in $50 \mathrm{ml}$ of water;

$-15 \mathrm{ml}$ of MBM solution, $35 \mathrm{ml}$ of water, $24.8 \mathrm{~g}$ of $\mathrm{CaCl}_{2}$ dissolved in $50 \mathrm{ml}$ of water;

$-9 \mathrm{ml}$ of bishophit mixed with $91 \mathrm{ml}$ of water;

$-12 \mathrm{ml}$ of bishophit mixed with $88 \mathrm{ml}$ of water;

$-46 \mathrm{ml}$ of bishophit mixed with $54 \mathrm{ml}$ of water.

The bottom of each pot had holes to allow a natural water run-off and prevent accumulation of excessive water. The seeds of white clover were simultaneously planted in clean and contaminated soils (experimental and control plants). Both the control and the experimental plants were grown under the same conditions - at the same temperature and lighting and were watered with identical water amounts at the same time.

Each experimental and control plant was watered with $40 \mathrm{ml}$ of water every three days.

The investigation determined the seed viability $(\%)$ and the length of above-ground part $(\mathrm{cm})$ of grass vegetation.

\section{Results and discussion}

\subsection{Results of the seed viability of grass vegetation}

A seed viability experiment was carried out twice in order to achieve reliable results.

100 seeds were placed in each bowl and one seed, therefore, was equated to one percent of viability.

The viability of white clover was over $90 \%$ during both experiments. The obtained results of viability are presented in Fig. 1 .

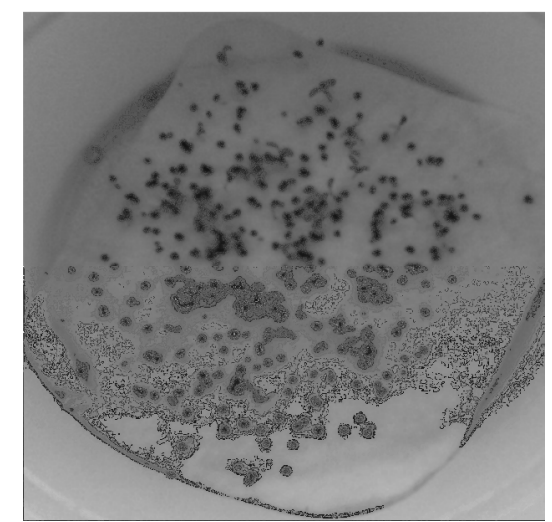

Fig. 1. Viability of white clover seeds

As the viability of the selected grass vegetation exceeded $90 \%$ it can be stated that the selected species are suitable for further investigation. 


\subsection{Results regarding the growth of grass vegetation in soil contaminated with different solutions}

As 100 seeds of white clover were seeded in each pot, the viability was determined in both control soil and soil contaminated with dust reducing and road slippery minimization agents. White clover was seeded in 10 pots in the following soils:

1) contaminated with MBM solution of $10 \%$ concentration;

2) contaminated with MBM solution of $20 \%$ concentration;

3) contaminated with MBM solution of $30 \%$ concentration;

4) contaminated with a mixture of $10 \% \mathrm{MBM}$ solution and $36.5 \% \mathrm{CaCl}_{2}$ concentration;

5) contaminated with a mixture of $20 \% \mathrm{MBM}$ solution and $36.5 \% \mathrm{CaCl}_{2}$ concentration;

6) contaminated with a mixture of $30 \% \mathrm{MBM}$ solution and $36.5 \% \mathrm{CaCl}_{2}$ concentration;

7) contaminated with bishophit solution of $9 \mathrm{ml}$ concentration;

8) contaminated with bishophit solution of $12 \mathrm{ml}$ concentration;

9) contaminated with bishophit solution of $46 \mathrm{ml}$ concentration;

10) non-contaminated (control).

The viability of white clovers in soil is represented in Fig. 2.

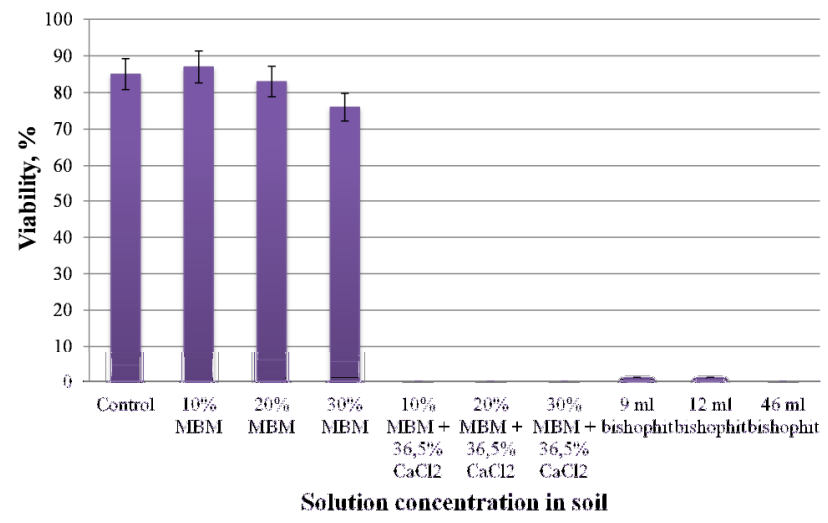

Fig. 2. Viability of white clovers in soil

As shown in Fig. 2, after 4 weeks of experiments white clover did not germinate in soil contaminated with mixtures of MBM and $\mathrm{CaCl}_{2}$ and in soil contaminated with $46 \mathrm{ml}$ of bishophit. Only one seed of white clover germinated in soil contaminated with 9 and $12 \mathrm{ml}$ of bishophit.

As mentioned in the methodology, the length of above-ground part was observed during experiments. The obtained results are presented in Figs 3-6. As no plants germinated in soil contaminated with the mixture of $\mathrm{MBM}^{\mathrm{and}} \mathrm{CaCl}$ and $46 \mathrm{ml}$ of bishophit the results are not presented.

During the $1^{\text {st }}$ week of experiment the clovers germinated in all pots except pots where soil was contaminated with $12 \mathrm{ml}$ of bishophit (Fig. 3).

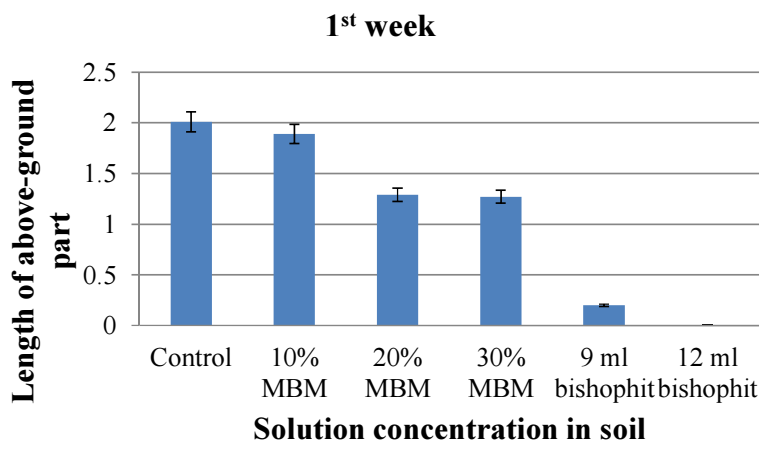

Fig. 3. Length of above-ground part of white clover after $1^{\text {st }}$ week of growth

In the $1^{\text {st }}$ week of growth room temperature was maintained at $20-21{ }^{\circ} \mathrm{C}$. The diagram (Fig. 3 ) shows that after the $1^{\text {st }}$ week the length of above-ground part of white clover in pot where soil was contaminated with $10 \%$ of MBM was only $0.12 \mathrm{~cm}$ smaller than control grass.

Difference in the length of above-ground part compared to the control one was: 1.06 times (10\% MBM in soil), 1.56 times (20\% MBM in soil), 1.58 times (30\% MBM in soil) and 10 times ( $9 \mathrm{ml}$ bishophit in soil). 
White clover (in pot with soil contaminated with $12 \mathrm{ml}$ of bishophit) started germinating in the experiment's $2^{\text {nd }}$ week. Room temperature rose to $22-23^{\circ} \mathrm{C}$ and the plants achieved significant growth in the $2^{\text {nd }}$ week (Fig. 4).

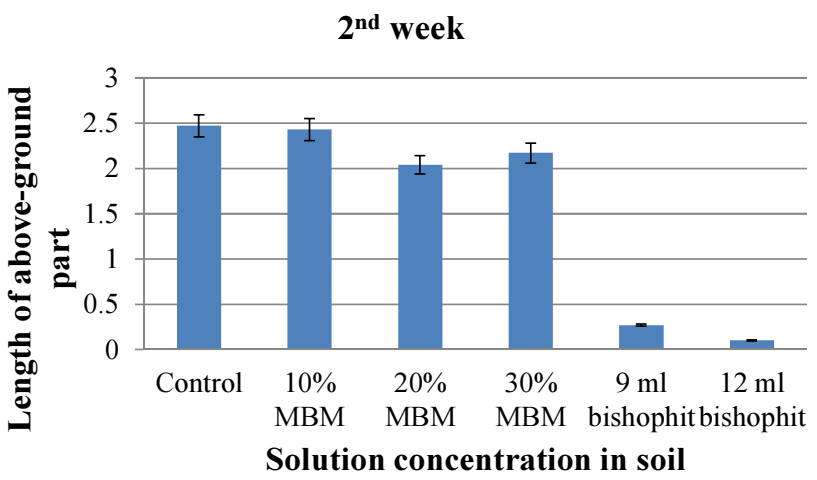

Fig. 4. Length of above-ground part of white clover after $2^{\text {nd }}$ week of growth

Difference in the length of above-ground part $2^{\text {nd }}$ week compared to the control one was: 1.02 times (10\% MBM in soil), 1.03 times (20\% MBM in soil), 1.14 times (30\% MBM in soil), 9 times (9 ml bishophit in soil) and 25 times (12 ml bishophit in soil).

White clover grown most in pot with soil contaminated with $20 \% \mathrm{MBM}$ during $2^{\text {nd }}$ week. Investigational plants grown $1.11 \mathrm{~cm}$ in this pot (control only $0.46 \mathrm{~cm})$. Clovers in others pots grew $0.54 \mathrm{~cm}(10 \% \mathrm{MBM}$ in soil), $0.9 \mathrm{~cm}(30 \% \mathrm{MBM}$ in soil), $0.07 \mathrm{~cm}$ (9 $\mathrm{ml}$ bishophit in soil) and $0.1 \mathrm{~cm}$ (12 $\mathrm{ml}$ bishophit in soil).

In the $3^{\text {rd }}$ week room temperature fell by $1{ }^{\circ} \mathrm{C}$ and was $21-22^{\circ} \mathrm{C}$. A fall in temperature had no big influence on the length of plants (Fig. 5).

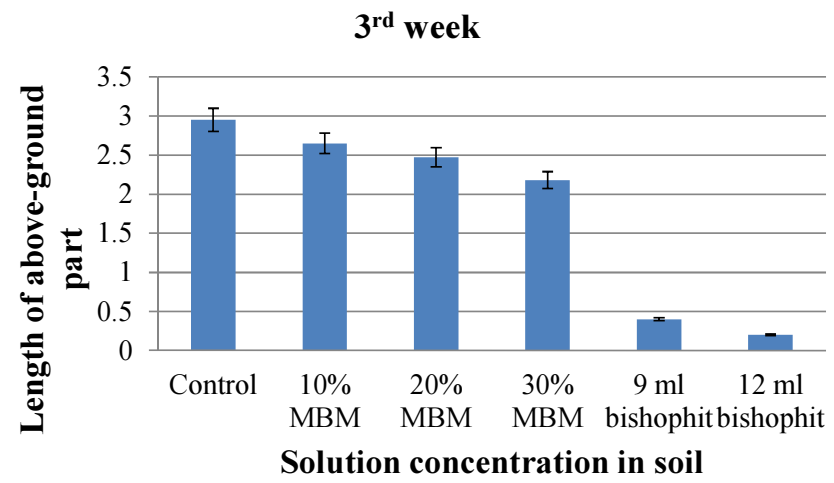

Fig. 5. Length of above-ground part of white clover after $3^{\text {rd }}$ week of growth

The length of control white clover plants reached $2.95 \mathrm{~cm}$. In soil contaminated with MBM solution of $10 \%$ concentration compared to control soil the above-ground part's length of white clover differed by 1.11 times, in soil with $20 \% \mathrm{MBM}-1.19$ times, 30\% MBM -1.35 times, $9 \mathrm{ml}$ of bishophit -7.38 times and $12 \mathrm{ml}$ of bishophit -15 times. Like in the $2^{\text {nd }}$ week it was clover in pot with soil contaminated with $10 \% \mathrm{MBM}$ that was the highest (except contral grass). In the $3^{\text {rd }}$ week clovers in pots with contaminated soil grew: $0.22 \mathrm{~cm}(10 \% \mathrm{MBM}$ in soil), $0.07 \mathrm{~cm}(20 \% \mathrm{MBM}$ in soil), $0.01 \mathrm{~cm}$ (30\% MBM in soil), $0.13 \mathrm{~cm}$ (9 $\mathrm{ml}$ bishophit in soil) and $0.1 \mathrm{~cm}(12 \mathrm{ml}$ bishophit in soil).

In the $4^{\text {th }}$ week room temperature rose by $2{ }^{\circ} \mathrm{C}$ and reaching $23-24{ }^{\circ} \mathrm{C}$. As a result of increased temperature the lengths of above-ground parts increased significantly (Fig. 6).

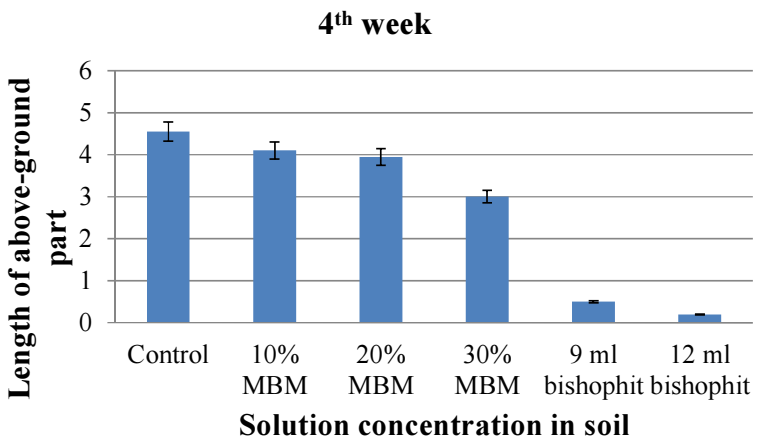

Fig. 6. Length of above-ground part of white clover after 4th week of growth 
The length of control white clover plants reached $4.55 \mathrm{~cm}$. In soil contaminated with MBM solution of $10 \%$ concentration compared to control soil the above-ground part's length of white clover differed by 1.11 times. Difference in the length of above-ground part $4^{\text {th }}$ week in others pots compared to the control one was: 1.15 times (20\% MBM in soil), 1.52 times (30\% MBM in soil), 9 times (9 ml bishophit in soil) and 23 times (12 $\mathrm{ml}$ bishophit in soil).

White clover grown most in pot with soil contaminated with $20 \% \mathrm{MBM}$ during $4^{\text {th }}$ week (except control grass). Investigational plants grown $1.48 \mathrm{~cm}$ in this pot (control $1.6 \mathrm{~cm})$. Clovers in others pots grew $1.45 \mathrm{~cm}(10 \% \mathrm{MBM}$ in soil), $0.82 \mathrm{~cm}$ (30\% MBM in soil), $0.1 \mathrm{~cm}$ (9 ml bishophit in soil) and $0.0 \mathrm{~cm}$ (12 ml bishophit in soil).

\section{Conclusions}

1. During the $1^{\text {st }}$ week of investigation no plants germinated in soils contaminated with molasses based material (MBM) $(10 \%, 20 \%, 30 \%)$ and $\mathrm{CaCl}_{2}(36.5 \%)$ mixtures and with $46 \mathrm{ml}$ of bishophit. This shows the negative impacts of these mixtures on the plants.

2. The length of above-ground part of white clover was not dependent on temperature fluctuations. During investigation temperature rose once and the length of the above-ground part of white clovers not showed a considerable increase. This means that temperature increase has a minor influence on the length of plants' above-ground parts of white clover.

3. After 4 weeks growing, white clover germinated in polluted soil: with molasses based material $(10 \%, 20 \%, 30 \%)$ viability was $76-87 \%$, with mixture of molasses based material $(10 \%, 20 \%, 30 \%)$ and calcium chloride $(36.5 \%)$ was $0 \%$, with bishophit $(9,12,46 \mathrm{ml})$ was $1 \%$.

4. During four weeks of investigation the plants achieved the following lengths of their above-ground parts: $4.55 \mathrm{~cm}$ in non-contaminated soil, $4.10 \mathrm{~cm}$ in soil contaminated with MBM solution of $10 \%$ concentration, $3.95 \mathrm{~cm}$ in soil contaminated with MBM solution of $20 \%$ concentration, $3.00 \mathrm{~cm}$ MBM solution of $30 \%$ concentration, $0.5 \mathrm{~cm}$ in soil contaminated with $9 \mathrm{ml}$ of bishophit concentration and $0.2 \mathrm{~cm}$ in soil contamined with $12 \mathrm{ml}$ of bishophit concentration. This shows the negative influence of $\mathrm{CaCl}_{2}$ on the plant's length.

5. $\mathrm{CaCl}_{2}$ has a negative effect on grass vegetation as during four weeks of investigation white clover not germinated in soil contaminated with a mixture. We recommend using MBM as more environmental friendly material for the road maintenance.

\section{References}

[1] Jonušienè, Z. 2000. Druska. Ką apie ją žinome? [Salt. What we know about it?], Mokslas ir gyvenimas [Science and life] 17(7): 12-19.

[2] Baltrénas, P.; Kazlauskienè, A.; Zaveckytè, J. 2006. Experimental investigation into toxic impact of road maintenance salt on grass vegetation, Journal of Environmental Engineering and Landscape Management 14(2): 83-88.

[3] Laurinavičius, A.; Čygas, D. 1998. Winter maintenance problems on the street of Lithuanian cities, Magazine X PIARC International Winter Road Congress, Lulea, 655-666.

[4] Blomqvist, G. 2001. De-icing salt and roadside environment: Air-borne exposure, damage to Norway spruce and system monitoring: PhD thesis summary. Stockholm, Swedish, VTI. $25 \mathrm{p}$

[5] Gajewska, B.; Rafalski, L. 2003. Vegetation cover in road environment, in The 25th International Baltic Road Conference, August 25-25, 2003. Vilnius, Lithuania. $11 \mathrm{p}$.

[6] Bivilienè, A. 2010. Lietuvos augalu nacionaliniai genetiniai ištekliai. Lietuvoje augančiu daugiamečiu žoliu genetine ivvairovė [Lithuanian national plant genetic resources. Lithuania-growing perennial herb of genetic diversity] Kèdainiai: UAB ,Spaudvila“ 21 p

[7] Tarakanovas, P.; Sprainaitis, A.; Chomiak, M. 2007. Baltujų dobilų veislių sausųų medžiagų derliaus stabilumas [Dry matter yield stability of cultivars (Trifolium repens L.) white clover], Žemdirbyste-Agriculture 94(4): 12-19.

[8] Smith, J.; Valenzuela, H. 2002. White Clover. Sustainable Agriculture cover crops, SA-CC-7.

[9] Infomine research group [online]. 2013. [Cited 12 December 2013]. Available from Internet: http://www.infomine.ru/otchets/en.

[10] Magnesium chloride [online]. 2013. [Cited 4 January 2014]. Available from Internet: www.meltsnow.com/products/magnesium/.

[11] SAFECOTE [online]. 2013. [Cited 12 December 2013]. Available from Internet: http://safecote.com.

[12] Inhibitorius SAFECOTE [online]. 2013. [Cited 12 December 2013]. Available from Internet: www.keluva.lt/? nm mid=TVN3eUxESXNNQ3d3\& nm lid $=0 \&$ session $=$ no

[13] Weiterová, I. 2008. Seasonal and Spatial Variance of Seed Bank Species Composition in an Oligotrophic Wet Meadow, Flora - Morphology, Distribution, Functional Ecology of Plants 203(3): 204-214. http://dx.doi.org/10.1016/j.flora.2007.03.003 